INTERNATIONAL JOURNAL OF RESEARCHES IN BIOSCIENCES, AGRICULTURE \& TECHNOLOGY (c) VISHWASHANTI MULTIPURPOSE SOCIETY (Global Peace Multipurpose Society) R. No. MH-659/13(N)

www.vmsindia.org

\title{
EFFECT OF GRADING ON QUALITY OF PEA SEEDS.
}

\author{
Prachi Lambat ${ }^{1}$ and Vandana S. Madke ${ }^{2}$ \\ ${ }^{1}$ Shri Mathuradas Mohota College of Science, Nagpur, M.S., India \\ ${ }^{2}$ Department of Botany, College of Agriculture, Nagpur -444 001 (M S.) \\ Email : lambatprachi@gmail.com
}

\begin{abstract}
:
Seed quality parameters and mycoflora associated with bold and wrinkled seeds of pea cv. Local-1 and Local-2 was investigated during 2018. Both types of seeds yielded qualitatively similar fungi viz., Alternaria alternate, Aspergillus flavus, A. niger, Culvularia lunata, Fusarium sp., Penicillium citrinum and Rhizopus nigricans, but for difference in their percentage of incidence. Percentage of seed colonized by fungi was more in wrinkled seeds in both cultivars. Bold seeds were superior with respect to seed quality parameters such as 100-seed weight, germination, plumule length, radical length and seedling dry weight as compared to wrinkled seeds.
\end{abstract}

Keywords: Fungi, germination, Plumule, radical, wrinkled seed.

\section{INTRODUCTION:}

Pea is an impotant pulse crop cultivated throughout India. Seed of pea is known to harbor several species of fungi. The invasion of fungi brings about the degradation of seed constituents, i.e. carbohydrates, protein, fat and vitamins and accumulation of toxic metabolites, thus rendering seeds unfit for useful purposes. Apart from this, seed germination and seedling vigour is also considerably affected. Hence, the present investigation was carried out on pea to study the effect of bold and wrinkled seed quality parameters and invasion of Fungal flora.

\section{MATERIALS AND METHODS}

Seed samples of pea cv. Local-1 and Local-2 were collected from State Seed Testing Laboratory, Nagpur and graded into two categories viz., bold and wrinkled seeds. The fungal flora associated with the seeds were detected by the standard moist blotter and agar medium techniques prescribed by ISTA ${ }^{1}$. The different types of fungal growth on the seeds were expressed in percentage. On these graded seeds were performed the following laboratory test such as 100-seed weight, Standard germination test, plumule length, radical length and dry weight of seedling.

\section{RESULTS AND DISCUSSION:}

It might be seen from the Table 1 that nine species of fungi viz. Alternaria atlernata,
Aspergillus flavus, Aspergillus niger, Cladosporium fulvum, Curvularia lunata, Fusarium moniliforme, Fusarium oxysporium, Penicillium citrinum and Rhizopus nigricans were isolated from the bold and wrinkled seeds of pea cv. Local-1 and Local-2. The incidence percentage of isolated fungal flora was higher on wrinkled seeds than those of bold seeds. Reddy and Subbayya ${ }^{3}$, Charjan and Tarar ${ }^{4}$ reported the percentage of seed colonized by fungi in the discoloured wrinkled seed of blackgram and greengram respectively was higher than those of normal bold seeds. Among the two cultivars, Local-1 showed higher incidence percentage of fungal flora in bold and wrinkled seeds than those of Local-2.

One hundred seed weight of the bold seeds showed higher than wrinkled seeds in both cultivar. Aguiar and Nakane ${ }^{5}$ also made similar observation. Similarly bold seeds were superior with respect to germination, plumule length, radical length and seedling dry weight as compared to wrinkled seeds. The results reported here are in conformity with the observations made by earlier workers 6,7. Probably reason for low germination in wrinkled seeds may be the presence of immature seeds ${ }^{8,9}$. The increased root length and seedling dry weight found in bold seeds, this might be due to efficient utilization of large food reserve and greater amount of production of energy. Similar observation has been made by Singh et $a l^{10}$. Teggi and Hiremath11 reported culture 
filtrate of Aspergillus flavus, Alternaria alternate, Colletotrichum $s p$. and Cladosporium fulvum affected the germination and seedling growth most severely.

The results suggested that it is desirable to avoid seed lot of pea with higher percentage of wrinkled seed for sowing or consumption purposes.

\section{REFERENCES :}

Anonymous (1976) : International rules for seed testing and annexes. Seed Science and technol. 4 : 108.

Anonymous (1985) : International rules for seed testing and annexes. Seed Science and technol. 13 : 299-513.

Reddy M R and J Subbayya (1980) : Mycoflora associated with discoloured seed of Pant U-30 blackgram. Seeds and Farms 6 : 32-33.

Charjan S U and J L Tarar (1993) : Studies on seed quality parameters and mycoflora associated with bold and wrinkled seeds of greengram (Vigna rediata L.) Bio journal 5 : 71-72.

Aguiar I B and J T Nakane (1983) : Seed size of Eucalyptus citriodora : Influence on germination and vigour. Seed (Abstr.) 12 : 2576.

Gurbanov Y V and Z G Bertii (1970) : Initial growth intensity in winter wheat in relation to seed size. Fld. Crop Abstr. 25 1275 .
Charjan S U, Wankhede S R and Jayade K G (2006) : Influence of seed size on germination and seedling vigour in cowpea varieties. In : Proc. of national Seminar on Economics of sustainability of dryland Agriculture, 67-69.

Kalakannavar R M, Shashidhara S D and Kulkarni G N (1989) : Effect of grading on quality of wheat seeds. Seed Res. 17 : 182-185.

Charjan S U and J L Tarar (1993) : Influence of seed size on germination and seedling vigour in soybean varieties. Bioved 2 : 165-168.

Teggi R V and Hiremath R V (1990Studies on seed mycoflora of shattering types of greengram. Seed Res. 18 : 139-143. 
Table 1. Mycoflora associated with bold and wrinkled seeds of cowpea cv. Local-1 and Local-2.

\begin{tabular}{|l|l|l|l|l|l|}
\hline $\begin{array}{l}\text { Sr. } \\
\text { No. }\end{array}$ & Name of Fungi & \multicolumn{2}{l}{ Local-1 } & \multicolumn{2}{l}{ Local-2 } \\
\hline 1. & Alternaria alternate & 5 & 10 & 3 & 7 \\
\hline 2. & Aspergillus flavus & 10 & 21 & 8 & 15 \\
\hline 3. & Aspergillus niger & 8 & 19 & 5 & 10 \\
\hline 4. & Cladosporium fulvum & 4 & 13 & 2 & 12 \\
\hline 5. & Curvularia lunata & 7 & 17 & 6 & 15 \\
\hline 6. & Fusarium moniliforme & 8 & 24 & 6 & 18 \\
\hline 7. & Fusarium oxysporium & 2 & 5 & 2 & 6 \\
\hline 8. & Penicillium citrinum & 9 & 19 & 5 & 9 \\
\hline 9. & Rhizopus nigricans & 8 & 27 & 5 & 19 \\
\hline Total incidence percentage of fungi & 61 & 155 & 42 & 111 \\
\hline
\end{tabular}

Table 2. Effect of bold and wrinkled seeds on quality parameters of pea cv. Local-1 and Local-2.

\begin{tabular}{|l|l|l|l|l|l|}
\hline $\begin{array}{l}\text { Category of } \\
\text { seeds }\end{array}$ & $\begin{array}{l}\text { 100- } \\
\text { seed } \\
\text { weight } \\
\text { (g) }\end{array}$ & $\begin{array}{l}\text { Standard } \\
\text { germination } \\
(\%)\end{array}$ & $\begin{array}{l}\text { Plumule } \\
\text { length } \\
\text { (cm) }\end{array}$ & $\begin{array}{l}\text { Radicle } \\
\text { length } \\
\text { (cm) }\end{array}$ & $\begin{array}{l}\text { Seedling } \\
\text { dry } \\
\text { weight (g) }\end{array}$ \\
\hline Local-1 & 10.19 & 96 & 19.92 & 27.42 & 0.79 \\
\hline Bold & 42 & 9.26 & 12.16 & 0.40 \\
\hline Wrinkled & 6.86 & 426 & 20.89 & 30.42 & 0.18 \\
\hline Local-2 & 9.98 & 98 & 10.96 & 14.96 & 0.47 \\
\hline Bold & 6.14 & 49 & \\
\hline Wrinkled &
\end{tabular}

